Article

\title{
Control of Penicillium glabrum by Indigenous Antagonistic Yeast from Vineyards
}

\author{
Catalina M. Cabañas ${ }^{1,2}$, Alejandro Hernández ${ }^{1,2, * \mathbb{C}}$, Ana Martínez ${ }^{1,2}$, Paula Tejero ${ }^{1,2}$, \\ María Vázquez-Hernández 1,2®D, Alberto Martín 1,2® and Santiago Ruiz-Moyano ${ }^{1,2}$ \\ 1 Nutrición y Bromatología, Escuela de Ingenierías Agrarias, Universidad de Extremadura, \\ Avd. Adolfo Suárez s/n, 06007 Badajoz, Spain; ccabaasc@alumnos.unex.es (C.M.C.); \\ amartinehi@alumnos.unex.es (A.M.); patejeroc@gmail.com (P.T.); m.vazquez.hern@gmail.com (M.V.-H.); \\ amartin@unex.es (A.M.); srmsh@unex.es (S.R.-M.) \\ 2 Instituto Universitario de Investigación en Recursos Agrarios (INURA), Avd. de la Investigación s/n, \\ Universidad de Extremadura, 06006 Badajoz, Spain \\ * Correspondence: ahernandez@unex.es
}

Received: 29 October 2020; Accepted: 9 December 2020; Published: 14 December 2020

check for updates

\begin{abstract}
Biocontrol is one of the most promising alternatives to synthetic fungicides for food preservation. Botrytis cinerea, Alternaria alternata, and Aspergillus section Nigri are the most concerning pathogens for grape development. However, frequently, other species, such as Penicillium glabrum in this study, are predominant in spoiled bunches. In this work, 54 native yeasts from vineyards were screened by direct confrontation in potato dextrose agar plates as antagonists against $P$. glabrum. Isolates of Pichia terricola, Aureobasidium pullulans, and Zygoascus meyerae were selected for their antagonist activity in vitro, plus isolates of Pichia kudriavzevii, Hormonema viticola, and Hanseniaspora uvarum were used as negative controls. However, in vivo, confrontations in wounded grapes showed disagreement with direct confrontation in vitro. P. terricola, $P$. kudriavzevii, H. viticola, Z. meyerae, and $H$. uvarum significantly reduced the incidence of P. glabrum on grapes. Nevertheless, P. terricola, $H$. viticola, and H. uvarum themselves spoiled the wounded grapes. Inhibitions were associated with different mechanisms such as the production of volatile organic compounds (VOCs), lytic enzymes, biofilm formation, and competition for nutrients. The isolates of P. kudriavzevii L18 (a producer of antifungal VOCs which completely inhibited the incidence of P. glabrum) and Z. meyerae L29 (with pectinase, chitinase and $\beta$-glucanase activity and biofilm formation which reduced $70 \%$ of the incidence of $P$. glabrum) are proposed as suitable biocontrol agents against P. glabrum.
\end{abstract}

Keywords: biocontrol; grapes; mechanism of action; volatile organic compounds; Penicillium

\section{Introduction}

A vineyard environment is a microbiologically complex ecosystem that harbors a wide variety of species of bacteria, yeast, and filamentous fungi [1]. Factors such as grape varieties, the stage of maturation, cultural practices, and climatic and geographical conditions define the diversity of the microbial population [2,3]. Among filamentous fungi, a relevant number of species have been described to spoil grapes or cause rotting of different parts of the plant. Alternaria alternata, Botrytis cinerea, and Cladosporium cladosporioides, together with Aspergillus spp. and Penicillium spp. are frequently isolated from different vineyards $[2,4,5]$.

Botrytis cinerea, the causal agent of Botrytis bunch rot, is the most concerning pathogen in grapes [6,7]. This pathogen overwinters as mycelium, sclerotia and/or necrotic tissues, and in spring, with favorable weather conditions, a large number of conidia are produced, which are dispersed by wind or water [8]. Botrytis bunch rot has a large impact on the quality of grapes and wines. Chemical changes, 
which include reduction of total phenolic compounds of seeds and skin because fungal laccases are well described [9]. Moreover, it is implicated in the production of earthy "off" aromas in wine by geosmin and other volatile compounds synthesis [10]. In addition, the presence of mycotoxigenic species such as Aspergillus niger, Aspergillus carbonarius and Aspergillus tubingiensis [2,11], which are producers of ochratoxin A (OTA), are other main sanitary concern in grape production. Although there is controversy about the prevalence of toxigenic strains, a higher percentage of toxigenic strains for $A$. carbonarius than other Aspergilli has been recorded [12]. Aspergillus species growth and OTA production are conditioned by climatology. In this sense, wines from the Mediterranean area are prone to accumulate OTA because the mold development is favorable [13]. Moreover, Aspergillus infections have an impact on the chemical composition of grapes [14] and wines, increasing levels of acids and terpenes [15]. Among Penicillium species, Penicillium expansum is currently receiving a great deal of attention because of the detection of patulin and citrinin in grapes and wines [16]. In addition, it is implicated, alone or combined with B. cinerea, in the production of earthy "off" aromas in wine by the production of geosmin [10]. Less attention has been paid to other spoiling species such as Penicillium glabrum, which together with other Penicillium spp. are responsible for secondary infections. Its presence has been widely described in the vineyards and the postharvest stage $[4,5,17,18]$. Bau et al. [19] reported that Penicillium citrinum and P. glabrum were the most frequently Penicillium isolated of 2800 grape berries from vineyards of different locations of the Spanish Mediterranean coast. Likewise, P. glabrum appeared as one of the most prevalent species of Penicillium in Brazilian [20] and Portuguese [21] grapes. Besides secondary infections in grapes, P. glabrum presence has been related to earthy, moldy, and mushroom odors associated with geosmin, 2-methylisoborneol, 1-octen-3-one, and 1-octen-3-ol [22] in must and wines [5] and other products [23]. Other studies showed the potential of P. glabrum to be an agent causing rotting in pomegranates $[24,25]$ and onion bulbs [26].

Nowadays, the application of chemical substances is the most widely used method to control pre and postharvest fungal disease. However, residues of fungicides on food commodities and their involvement in environmental and human toxicity generate social concern [27]. Moreover, the development of resistance to fungicides by strains of pathogenic molds is a serious threat for managing the crops. Concretely, resistant strains of pathogenic species related to vineyards as B. cinerea [28], P. expansum [29] and Aspergillus spp. [30] have widely been documented. In recent decades, efforts to replace chemical fungicides with environmentally friendly and less toxic treatments have multiplied [31]. Standing out among them is biological control. The characteristics of ideal biocontrol agents enumerated by Droby et al. [32], such as genetic stability, effectiveness against a wide range of pathogens, non-detrimental to human health, allow reducing the use of chemical compounds. The complex microbial population present in vineyards and berry grapes harbor multiple species with antagonistic potential [1]. Botrytis cinerea has been the main target for biocontrol studies. Among bacteria, Bacillus subtilis, Pantoea agglomerans, Pantoea ananatis, Pseudomonas fluorescens, and Acinetobacter lwoffii isolated from vineyard environments have proved to have remarkable antagonistic activity against $B$. cinerea $[6,33,34]$. A high diversity of yeast species isolated from vineyards have been described as antagonistic agents against $B$. cinerea. Wang et al. [7] reported effective control by Aureobasidium pullulans, Metschnikowia chrysoperlae, Metschnikowia pulcherrima, Meyerozyma guilliermondii, and Saccharomyces cerevisiae. Volatile organic compounds produced by Starmarella bacilaris [35] and the competition for nutrients by A. pullulans [36] and Hanseniaspora uvarum [6] are effective ways to control B. cinerea. Different studies about the biological control of species of Aspergillus section Nigri producers of OTA are presented in the literature. Bacillus amyloliquefaciens, B. pumilus, and Lactobacillus plantarum $[37,38]$ among bacteria; yeast species as A. pullulans, Kluyveromyces thermotolerans, M. pulcherrima, H. uvarum [39-42]; and filamentous fungi as Acremonium cephalosporium [43] were efficient antagonists against $A$. carbonarius, and A. nigri; besides of producing a remarkable reduction of OTA accumulation on grapes. Works directed to control Penicillium development in grapes and vineyards by antagonistic agents are limited and mainly focused 
on P. expansum [44-46] and to a lesser extent to Penicillium commune [39], Penicillium digitatum [47] are other species of this genus. Nevertheless, the biological control of P. glabrum has not been still addressed.

In this work, screening for antagonistic yeast detection was performed against $P$. glabrum isolated from spoiled grape bunches. A preliminary mechanism of activity characterization was performed. Finally, the antagonistic capability was evaluated by confronting yeasts and molds in grapes.

\section{Material and Methods}

\subsection{Sampling, Microbial Counts, and Isolation of Molds and Yeast}

Samples were taken from one vineyard of the "Pardina" variety (white variety, Vitis vinifera). from Lobón ( $38^{\circ} 49^{\prime} 33.41^{\prime \prime} \mathrm{N} ; 6^{\circ} 37^{\prime} 34.78^{\prime \prime} \mathrm{W}$, Badajoz, Spain) in the year 2018. The maximum temperature observed in high summer in this region was $44.7^{\circ} \mathrm{C}$, and the annual accumulated precipitation was $488.6 \mathrm{~mm}$ (Köppen climate classification = Csa). Sampling was performed according to previous works [42]. Ten damaged and ten healthy grape bunches were selected at harvest time from twenty different plants across two diagonal transects. Samples were taken under aseptic conditions and were kept to $<7^{\circ} \mathrm{C}$ until analyses.

Microbial counts were performed by randomly selecting ten berry grapes from each bunch. After this, the samples were serially diluted with peptone water and plated in acidified potato dextrose agar (PDA, Condalab, Spain) to $\mathrm{pH} 3.5$ with a sterilized solution of tartaric acid at $10 \%(w / v)$. The plates were incubated at $25^{\circ} \mathrm{C}$ for 5 days, and the results were expressed as $\log _{10} \mathrm{CFU} / \mathrm{g}$ of grapes. The microbial analyses were performed in triplicate.

Isolation of yeasts and molds were performed based on colony morphology. Two-three colonies of each morphology and sample were selected from the highest diluted plates. Yeast isolates were selected from healthy bunches, whereas mold isolates were selected from damaged bunches. Each colony was streaked out on acidified PDA plates two consecutive times until pure colonies were obtained. After this, the isolates were stored in $40 \%$ sterile glycerol $(v / v)$ at $-80{ }^{\circ} \mathrm{C}$.

\subsection{Identification of Isolates}

Genomic DNA from microbial isolates, yeast and molds, was extracted using the NucleoSpin ${ }^{\circledR}$ Microbial DNA kit (Macherey-Nagel, Düren, Germany) according to the manufacturer's instructions. To identify the isolates at the species level, the internal transcribed spacer ITS1/ITS2-5.8S rRNA region was amplified as detailed by Gallardo et al. [48] using the primer pairs ITS1 and ITS4 [49]. PCR reactions were run in a $\mathrm{T} 100^{\mathrm{TM}}$ thermal cycler (Bio-Rad, Hercules, CA, USA) using an initial denaturation at $94^{\circ} \mathrm{C}$ for $4 \mathrm{~min}$, followed by 35 cycles of $94^{\circ} \mathrm{C}$ for $1 \mathrm{~min}$, annealing at $55^{\circ} \mathrm{C}$ for $1 \mathrm{~min}$, elongation at $72{ }^{\circ} \mathrm{C}$ for $1 \mathrm{~min}$, and a final extension at $72{ }^{\circ} \mathrm{C}$ for $10 \mathrm{~min}$. PCR products were purified using the GeneJET PCR purification kit (Thermo Fisher Scientific) and then sequenced at the Service of Bioscience Applied Techniques (STAB) of the University of Extremadura (Badajoz, Spain). The sequences were analyzed and edited with Chromas Pro version 1.49 beta (Technelysium, Queensland, Australia) and checked by nucleotide-nucleotide comparison with EMBL/GenBank databases using the BLAST algorithm. The identities of the isolates were determined based on the highest score. The accession numbers of the reference strains are included in the Results section.

Identities of mold isolates identified as P. glabrum were confirmed by amplification of the D1/D2 domain of the 26S large ribosomal subunit (LSU) of rRNA using the primers NL1 and NL4 following the PCR conditions described by Gallardo et al. [48], $\beta$-tubulin gene using primers Bet2a and Bet2b [50] and calmodulin gene using primers CMD5 and CMD6 [51]. PCR amplification was performed in $50 \mu \mathrm{L}$ of reaction mixtures containing $10 \mathrm{ng}$ of genomic DNA, $50 \mathrm{pmol}$ of the forward primer and reverse primer, $0.2 \mathrm{mM}$ of each dNTP, $0.1 \mathrm{vol}$ of 10X PCR buffer, and 1.25 U Green DreamTaq DNA polymerase (Fermentas, Thermo Fisher Scientific Inc., MA, USA). PCR reactions and PCR amplicons were carried out and sequenced as above. 
Additionally, strain typing into $P$. glabrum isolates was performed with inter single sequence repeat-PCR (ISSR-PCR) markers (CAG) 4 (5'-ARRTYCAGCAGCAGCAG-3'), (GTG) 5 (5'-GTGGTGGTGGTGGTG-3'), UBC809 (5'-AGAGAGAGAGAGAGAGG-3'), and UBC817 (5'-CACACACACACACACAA- $3^{\prime}$ ) following the PCR conditions described by Gallardo et al. [48]. Amplification products were separated on a $2 \%$ agarose gel stained with Midori Green Advance (Nippon, Japan). The GeneRuler 100 bp plus DNA ladder (Thermo Fisher Scientific, San José, CA, USA) was used as the reference.

\subsection{Screening for Antagonistic Activity by Direct Confrontation}

Penicillium glabrum isolates M1307 and M204 were used as a target for the screening of the antagonistic activity of isolated yeasts.

Inocula of mold and yeast were prepared as follows: conidia suspensions were obtained by growing P. glabrum isolates on acidified PDA at $25^{\circ} \mathrm{C}$ for 7 days. The conidia were collected in distilled water with $0.05 \%(v / v)$ Tween-80 (Scharlab, Spain). Finally, spores were counted in a Neubauer chamber and adjusted to $10^{5}$ conidia $/ \mathrm{mL}$.

The isolates of yeasts were grown in acidified PDA plates at $25{ }^{\circ} \mathrm{C}$ for $48 \mathrm{~h}$. A loop of cells was collected and resuspended in $500 \mu \mathrm{L}$ of sterile distilled water. Finally, the cells were counted in a Neubauer chamber and adjusted to $2 \times 10^{7}$ cells $/ \mathrm{mL}$.

Determining the antagonistic capability of yeast strains against $P$. glabrum isolates was done by challenging the yeasts with pathogenic mold isolates on acidified PDA plates. Two hundred microliters from a conidia solution were added to the surface of each agar plate and spread out. After drying, $5 \mu \mathrm{L}$ of yeast suspension from each isolate were placed on agar plates. As controls, agar plates seeded with conidia solutions from each pathogenic mold isolate were inoculated with $5 \mu \mathrm{L}$ of sterile distilled water instead of the yeast suspension. The plates were incubated for 5 days at $25^{\circ} \mathrm{C}$. Modifications in the growth of molds on the yeast plates were compared to the control plates. The confrontations were performed in triplicate. The yeast isolates that induced the largest modifications in mycelial growth were selected for subsequent assays. In addition, yeast isolates without remarkable interactions with P. glabrum were also selected as negative controls.

\subsection{Characterization of the Mechanism of Antagonism}

\subsubsection{Production of Antifungal Volatile Organic Compounds}

A double-dishes system (DDS) of acidified PDA was used to determine the production of antifungal VOCs by yeast as described by Ruiz-Moyano et al. [52].

The diameter of the mycelia was measured daily. As a control, a DDS was performed without the inoculation of yeasts. The confrontations with all isolates of yeast were done in triplicate, and the trial was carried out twice. The lag phase (expressed in days) and growth rates (expressed as mm day ${ }^{-1}$ ) and the reduction of P. glabrum growth were calculated on the fourth day of confrontation. After this, the results were expressed as differences between confrontations and the control (without yeasts).

Analyses and identification of volatile compounds produced by yeasts were performed as Ruiz-Moyano et al. [52]. The extraction of compounds from DDS was conducted by solid-phase microextraction (SPME) with a $10 \mathrm{~mm}$-long, $75 \mu \mathrm{m}$-thick fiber coated with Carboxen/polydimethylsiloxane (Supelco, Bellefonte, PA, USA). The analysis was done in a GC/MS using an Agilent 6890 GC-5973 MS system (Agilent Technologies, Little Falls, DE, USA) equipped with a 5\% phenyl-95\% polydimethylsiloxane column $(30 \mathrm{~m} \times 0.32 \mathrm{~mm}$ inner diameter, $1.05 \mu \mathrm{m}$ film thickness, Hewlett-Packard, Palo Alto, CA, USA).

\subsubsection{Effect of Antagonistic Yeasts on Spore Germination of Pathogenic Molds}

Effect of yeast on conidia was performed according to Ruiz-Moyano et al. [53]. Aliquots (100 $\mu \mathrm{L})$ of a suspension of $10^{5}$ conidia/mL of P. glabrum isolates were spread out on acidified PDA plates. 
After drying, $100 \mathrm{~mL}$ of selected yeast solutions $\left(2 \times 10^{5}, 2 \times 10^{6}, 2 \times 10^{7}\right.$ cells $\left./ \mathrm{mL}\right)$ were spread out in the same plate. The plates were incubated at $25^{\circ} \mathrm{C}$. Over 100 conidia were observed to assess the germination rate by measuring the germ tube at $10 \mathrm{~h}$. The reduction in the percentage of spore germination was calculated by comparison with the control plates without yeast inoculation. In addition, the size of the germ tubes was compared with controls without inoculation of yeasts. Germ tubes were measured by observation and analyses at 20X magnification with sub-stage illumination (DMLS, Leica, Buccinasco, MI, Italy) using a Leica DM 2000 LED microscope. The experiment was performed in triplicate.

\subsubsection{Parasitism of P. glabrum hyphae}

The determination of the interaction between selected yeasts and P. glabrum isolates was evaluated on PDA plates ( $8 \mathrm{~mL}$ per plate) according to Ruiz-Moyano et al. [53]. Samples of $5 \mu \mathrm{L}$ of conidia suspensions were inoculated in the middle of the plates. Then, $5 \mu \mathrm{L}$ of yeast cell suspensions $\left(10^{6}\right.$ cells $\left./ \mathrm{mL}\right)$ were inoculated at the border of the mold inocula. The interaction was observed after 12,24 , and $48 \mathrm{~h}$ of incubation at $25^{\circ} \mathrm{C}$. Then the cultures were washed under tap water for $60 \mathrm{~s}$, and the plates were observed with a Leica DM 2000 LED microscope.

\subsubsection{Production of Antifungal Extracellular Substances}

\section{Antibiosis}

The capacity to produce extracellular antifungal substances was evaluated by subculturing selected yeast in a liquid medium. Sterile yeast extract peptone dextrose broth (YPD, Condalab), potato dextrose broth (PD, Condalab), and yeast malt broth (YM: yeast extract, $3 \mathrm{~g} / \mathrm{L}$; malt extract, $3 \mathrm{~g} / \mathrm{L}$; peptone, $5 \mathrm{~g} / \mathrm{L}$; and glucose, $10 \mathrm{~g} / \mathrm{L}$; Condalab) were used for this assay. Three different inocula were performed in $10 \mathrm{~mL}$ of culture broth, incubated at $25^{\circ} \mathrm{C}$ for 2 days: $50 \mu \mathrm{L}$ of selected yeasts $\left(2 \times 10^{7}\right.$ cells $\left./ \mathrm{mL}\right)$, co-inoculation of selected yeasts and conidia $\left(50 \mu \mathrm{L}\right.$ of $10^{5}$ conidia/mL), and inoculation of selected yeast in culture broth supplemented with inactivated hyphae. The inactivation on hyphae consisted of the cultivation of $50 \mu \mathrm{L}$ of conidia solution on $10 \mathrm{~mL}$ of culture broth at $25^{\circ} \mathrm{C}$ for 5 days at $100 \mathrm{rpm}$. After this, the cultures were autoclaved at $121{ }^{\circ} \mathrm{C}$ for $16 \mathrm{~min}$. Then, $1 \mathrm{~mL}$ of broth was centrifuged to $5000 \times g$ for $5 \mathrm{~min}$. The pellet was used to supplement the $10 \mathrm{~mL}$ of culture broth.

After incubation, $5 \mathrm{~mL}$ were centrifuged at $10,621 \times g$ for $5 \mathrm{~min}$, and supernatants were sterilized by filtration ( $22 \mu \mathrm{M}$ of pore size). Sterile paper discs were immersed in the extracellular extracts for $5 \mathrm{~s}$. After this, the discs were set in PDA plates previously seeded with $100 \mu \mathrm{L}$ of $10^{5}$ conidia/mL. Plates were incubated at $25^{\circ} \mathrm{C}$ for $48 \mathrm{~h}$, and alterations in mycelia growth and inhibition halos were recorded.

\section{Production of Lytic Enzymes}

Three different enzymatic activities related to the degradation of cell walls were tested. Five $\mu \mathrm{L}$ of cell solution $\left(10^{7}\right.$ cells $\left./ \mathrm{mL}\right)$ were inoculated in each culture medium. Chitinase activity and $\beta$-glucanase activity were determined, as previously described by Cordero-Bueso et al. [54], using YPD agar (Condalab) supplemented with $0.2 \%$ of chitin (Sigma, St. Louis, MO, USA) and $0.2 \% \beta$-glucan (Sigma, St. Louis, MO, USA), respectively and revealed with Congo red. The presence of red halos was recorded. Pectinase activity was analyzed in plates of YPD agar supplemented with 10\% apple pectin (Sigma, St. Louis, MO, USA). After 5 days of incubation at $25^{\circ} \mathrm{C}$, plates were flooded with $10 \%$ cetyl trimethyl ammonium bromide (CTAB). The presence of clear halos was recorded. Finally, protease activity was evaluated in 10\% skim milk powder (AppliChem, Darmstad, Germany) and $2 \%$ of bacteriological agar [55]. The assays were repeated three times.

\subsubsection{In Vitro Biofilm Formation}

The determination of in vitro biofilm formation was performed as detailed by Cordero-Bueso et al. [54]. Briefly, $10 \mu \mathrm{L}$ of fresh suspension were inoculated in $1 \mathrm{~mL}$ of yeast nitrogen base (YNB, Condalab) with $100 \mathrm{mM}$ glucose and incubated overnight at $28{ }^{\circ} \mathrm{C}$. Subsequently, the tubes were 
centrifuged at $2935 \times g$ for $5 \mathrm{~min}$. The supernatant was discarded, and the pellets were washed twice with a 1X phosphate-buffered saline solution (PBS, Thermo Fisher Scientific, Madrid, Spain) and resuspended in YNB + glucose $(100 \mathrm{mM})$ medium to obtain $10^{7} \mathrm{CFU} / \mathrm{mL}$.

The adhesion phase was achieved by inoculating $100 \mu \mathrm{L}$ of the cell suspension into a 96-well polystyrene plate with a flat bottom (Thermo Fisher Scientific) at $28^{\circ} \mathrm{C}$ and shaking in a shaker at $90 \mathrm{rpm}$ for $3 \mathrm{~h}$. The wells were washed twice with $150 \mu \mathrm{L}$ of PBS, then $100 \mu \mathrm{L}$ of the same medium were added into each well, and the plate was incubated at $28^{\circ} \mathrm{C}$ in a shaker at $90 \mathrm{rpm}$ for $72 \mathrm{~h}$. The medium was taken daily and replaced by $100 \mu \mathrm{L}$ of fresh YNB + glucose. After incubation, the wells were washed twice with $150 \mu \mathrm{L}$ of PBS; then $100 \mu \mathrm{L}$ of crystal violet $0.4 \%(w / v)$ were put into each well for $45 \mathrm{~min}$. Not-fixed colorant was washed four times, with $150 \mu \mathrm{L}$ of sterile distilled water, and, finally, $200 \mu \mathrm{L}$ of $95 \%(v / v)$ ethanol was added. After $45 \mathrm{~min}, 100 \mu \mathrm{L}$ of solution were transferred to a new polystyrene $96-w e l l$ plate and measured at $590 \mathrm{~nm}$. The absorbance values were subtracted from the control test values without yeast inoculation. Each yeast strain was evaluated in triplicate.

\subsubsection{Competition for Nutrients}

Two methods were performed for the evaluation of competition for nutrients. First, depletion of iron was evaluated as previously described by Cordero-Bueso et al. [54] using PDA plates and PDA supplemented with 5 and $20 \mu \mathrm{g} / \mathrm{mL}$ of $\mathrm{FeCl}_{3}$. One hundred $\mathrm{mL}$ of spore suspension $\left(10^{5}\right.$ conidia/mL) were spread on plates. Then, $5 \mu \mathrm{L}$ of yeast cell solutions $\left(10^{7} \mathrm{cells} / \mathrm{mL}\right)$ were inoculated on PDA plates over spore suspensions. The plates were incubated at $25^{\circ} \mathrm{C}$ for 7 days; then, a comparison of the inhibition halos was recorded.

The second method for the antagonistic mechanism based on competition for nutrients was an inoculation assay on wounded grapes performed as previously described by Ruiz-Moyano et al. [53]. Grapes were sterilized by immersion for $3 \mathrm{~min}$ in $100 \mathrm{ppm}$ sodium hypochlorite, then rinsed with sterile distilled water and dried by air. One lesion was made in each berry with a sterilized tip ( $3 \mathrm{~mm}$-wide $\times 3 \mathrm{~mm}$-deep). Treatments involved the inoculation of $10 \mu \mathrm{L}$ of $2 \times 10^{7}$ cells $/ \mathrm{mL}$ of selected yeasts, followed by the addition of $3 \mu \mathrm{L}$ of $10^{5}$ conidia/mL of molds. The confrontations were also repeated by adding $10 \mu \mathrm{L}$ of yeast nitrogen base (Condalab) in independent treatments. As controls, molds were inoculated alone.

Each inoculated grape was set in a sterile plastic bottle at $25{ }^{\circ} \mathrm{C}$ for 5 days. Periodically, the percentage of infected lesions was recorded. A significant increment of incidence of P. glabrum by the addition of YNB was recorded as positive competition for nutrients. Ten grapes were used per treatment, and the assay was repeated three times.

\subsubsection{In Vivo Assay and Competition for Nutrients Determination}

The in vivo assay consisted of a comparison of the incidence of each of the strains of P. glabrum in wounded grapes when the selected yeasts were confronted. The procedure was the same as described in the previous section without the addition of nutrients. Thirty wounded grapes were used in each assay, and the experiment was repeated 3 times.

\subsubsection{Analysis of Results}

Statistical analysis of the data was performed with the SPSS software package for Windows version 19.0 (SPSS Inc., Chicago, IL, USA). Percentages were converted into Bliss angular values before analysis. Differences in the mean values of percentage of germination, germ tube size, lag phase, growth rate, inhibition of growth, and incidence of disease were tested by one-way analysis of variance and separated by Tukey's honestly significant difference test $(p \leq 0.050)$. 


\section{Results}

\subsection{Microbial Counts and Species Identification of Yeasts and Molds}

The mean counts of yeast were $6.66 \pm 1.08$ and $3.91 \pm 2.73 \log _{10}$ CFU/g $(p=0.021)$ in healthy and damaged bunches, respectively. No statistical differences were found in the mold population between healthy and damaged bunches, with values of $3.74 \pm 2.57$ and $4.39 \pm 1.84 \log _{10}$ CFU/g $(p=0.516)$, respectively.

A total of 54 yeasts were isolated from healthy grape samples. Molecular identification by sequencing of ITS1-5.8S rDNA-ITS4 gave six different species (Table 1). Aureobasidium pullulans and P. terricola (formerly Issatchenkia terricola) were isolated from all samples analyzed. This was followed by Pichia kudriadzevii (formerly Issatchenkia orientalis) isolated from 8 samples, H. uvarum (4 samples), Hormonema viticola (2 samples), and Zygoascus Meyerae (1 sample). All sequences presented identities above $99 \%$ with the accession number previously deposited on the GenBank database.

Table 1. Yeast species identification (species, percentage of identity, and accession number of reference), number of isolates, and presence of the species per 10 bunches.

\begin{tabular}{ccccc}
\hline $\mathbf{N}^{\circ}$ Isolates & $\begin{array}{c}\text { Presence Per } \\
\text { Ten Bunches }\end{array}$ & $\begin{array}{c}\text { Species } \\
\text { Identification }\end{array}$ & $\begin{array}{c}\text { Percentage of } \\
\text { Identity }\end{array}$ & $\begin{array}{c}\text { Accession } \\
\text { Number }\end{array}$ \\
\hline 13 & 10 & Yeasts & \\
\hline 8 & 6 & $\begin{array}{c}\text { Pichia terricola } \\
\text { Pichia kudriavzevii } \\
\text { Aureobasidium } \\
\text { pullulans }\end{array}$ & 100 & NR153994 \\
17 & 10 & $\begin{array}{c}\text { Hanseniaspora } \\
\text { uvarum }\end{array}$ & 99.86 & KY103573 \\
8 & 4 & Hormonema viticola & 99.82 & NR137620 \\
6 & 2 & Zygoascus meyerae & 100 & KY106012 \\
\hline 2 & 1 & Filamentous fungi & & \\
\hline 18 & 10 & Penicillium glabrum & 100 & AY373915 \\
1 & 1 & $\begin{array}{c}\text { Cladosporium } \\
\text { cladosporioides }\end{array}$ & 100 & HQ832794 \\
11 & 4 & Alternaria alternata & 100 & MG733652 \\
3 & 2 & Aspergillus nigricans & 100 & KP124341 \\
\hline
\end{tabular}

Regarding the mold population, a total of 33 isolates of molds were obtained from grape bunches with symptoms. These were clustered in four species (Table 1). Penicillium glabrum was the most isolated species; it was present in all damaged bunches. Four samples presented only morphologies compatible with P. glabrum. Moreover, A. alternata was detected in 4 damaged bunches; Aspergillus nigricans in two, and Cladosporium cladosporioides only in one damaged bunch.

According to the incidence of P. glabrum in damaged samples, this species was the objective for the biocontrol screening with the isolated yeasts. Accurate genetic identification of P. glabrum was performed in the 18 isolates by also sequencing large subunit (LSU) $26 \mathrm{~S}$ rDNA, $\beta$-tubulin, and calmodulin genes. Identical sequences on ITS1-5.8S rDNA-ITS4 and LSU 26S rDNA were found in P. glabrum isolates. However, two different groups of sequences were found on $\beta$-tubulin ( 5 substitutions and one indel) and calmodulin (3 substitutions) sequences. Intraspecific differences were confirmed by comparison of profiles of four ISSR-PCR markers. The 18 isolates were grouped into the two intraspecific groups cited before based on the differences in one band with (CAG) $)_{4}$, two bands with $(\mathrm{GTG})_{5}$, three bands with UBC809, and one band with UBC817 (Figure 1). One member of each genetic subgroup was selected for the screening of antagonistic activity with the selected yeasts. 


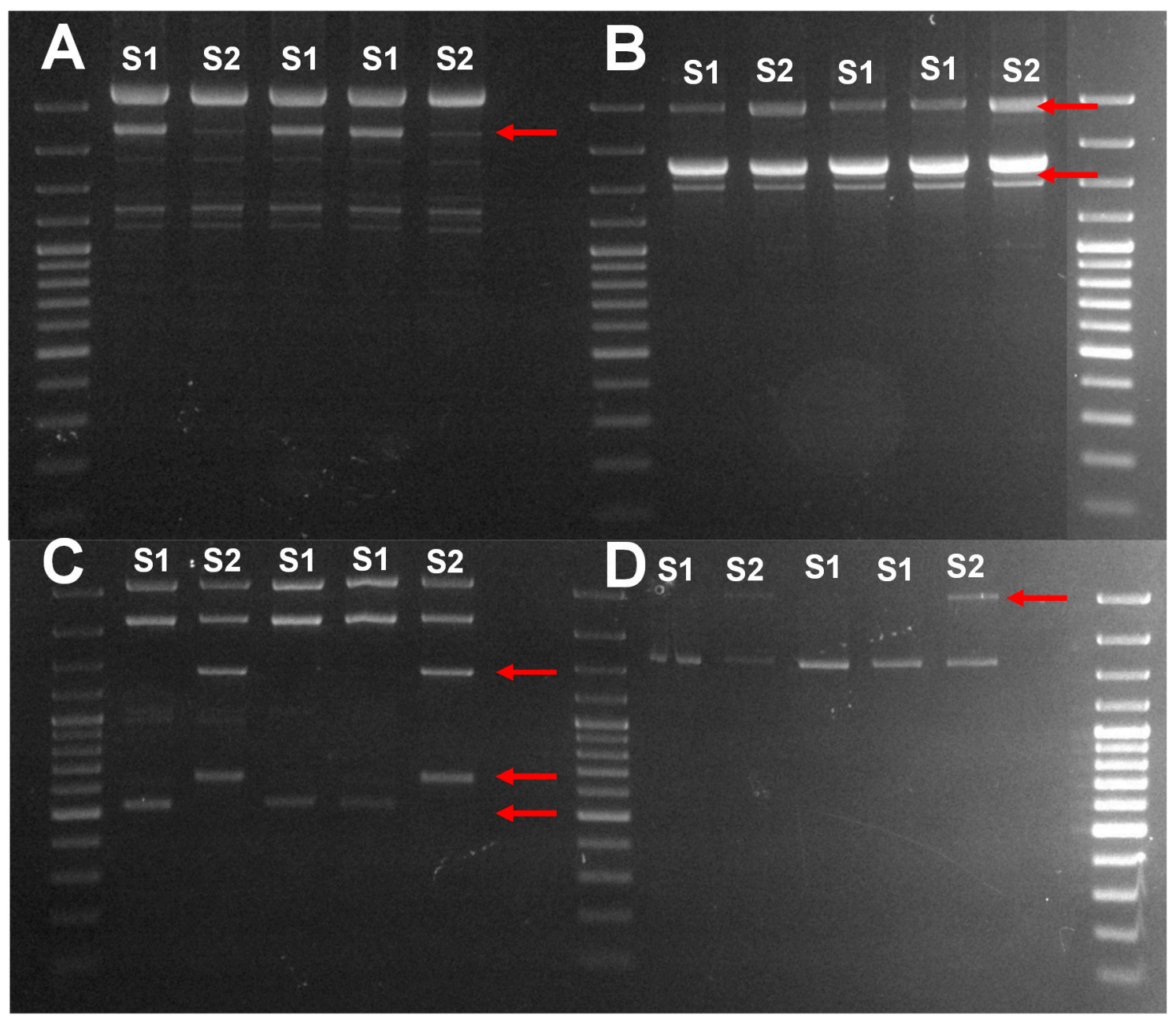

Figure 1. Agarose gel of ISSR-PCR profiles of 5 isolated of $P$. glabrum with primers (A) (CAG) 4 ; (B) (GTG) 5 ; (C) UBC809 and (D) UBC817. S1 and S2 track show profiles of the two genetic subgroups of P. glabrum.

\subsection{Screening of Antagonistic Activity by Direct Confrontation}

The 54 isolates of yeast (Table 1) were confronted with the two P. glabrum strains selected. Different types of interactions were detected. Isolates belonging to P. kudriavzevii and H. uvarum species were covered by P. glabrum hyphae, as shown in Figure 2A. Other yeasts, such as Z. meyerae isolates, showed a neutral behavior (Figure 2B). These yeasts grew in the inoculation area and did not modify the mycelia. Most of $A$. pullulans isolates showed a null capacity for competition against P. glabrum, which completely covered areas of inoculation. However, two isolates showed a different interaction with the most intense sporulation appearing around the colony (Figure 2C) and inhibition halo (Figure 2F). Hormonema viticola isolates were covered by mold, although hyphae were visually modified (Figure 2D). Finally, seven out of 18 isolates of $P$. terricola presented a clear halo without hyphae surrounding the inoculation area. Visual appearance indicated that a clear zone could be associated with colonization of the space more than with the secretion of inhibitory substances. The isolates produced halo sizes ranging from 2 to $8 \mathrm{~mm}$. 

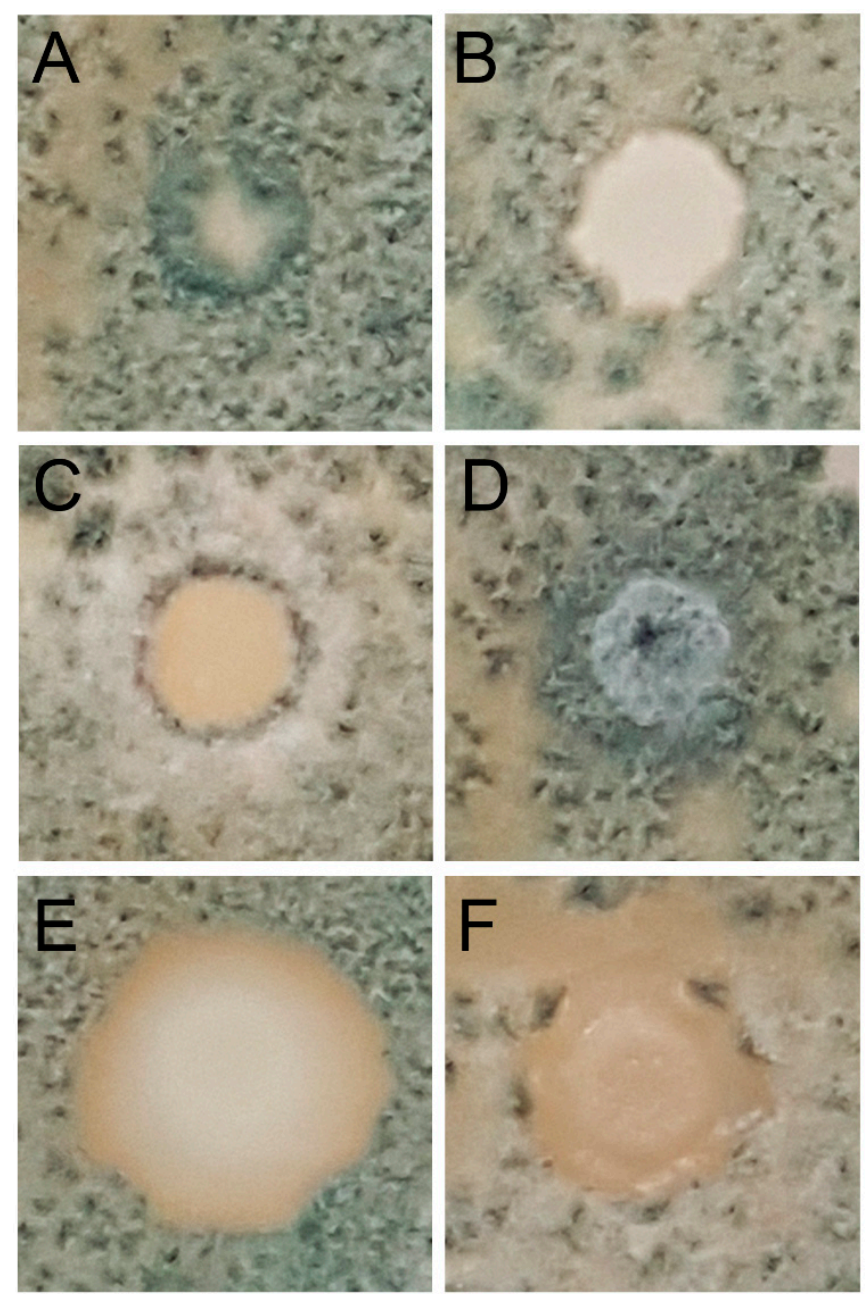

Figure 2. Images of direct confrontation between P. glabrum and H. uvarum (A), H. viticola (B), A. pullulans (C,F); Z. meyerae (D), and P. terricola (E).

Based on results of direct confrontation with the two strains of $P$. glabrum resulting in the inhibition or modification of its growth, the isolates P. terricola L14, A. pullulans L30 and L31, and H. viticola L21 were selected for subsequent characterization of their antagonistic activity mechanisms. P. kudriavzevii L18, Z. meyerae L29, and H. uvarum L35 were used as negative controls for activity.

\subsection{Characterization of the Mechanism of Antagonistic Activity against P. glabrum}

First, regarding VOCs production by selected yeasts in control double dish systems without yeast, P. glabrum grew at $5.45 \pm 0.07$ (strain PG1307) and $5.51 \pm 0.16$ (strain PG204) $\mathrm{mm}^{-1 a y}{ }^{-1}$ at $25^{\circ} \mathrm{C}$. In the confrontations, the growth rate of P. glabrum 1307 significantly decreased with the volatile compounds produced by P. kudriavzevii L18 $(p<0.001)$ (Table 2). The rest of the confrontations did not inhibit mold growth rates; an increase in the growth rate was even detected for PG204. The lag phase of P. glabrum, $0.86 \pm 0.01 \mathrm{day}^{-1}$ for PG1307 and $0.61 \pm 0.09 \mathrm{day}^{-1}$ for PG204, were increased in the presence of volatile yeast compounds from P. terricola L14 and P. kudriavzevii L18. The values of the lag phase increased to 1.52 and 1.65 days $^{-1}$ for PG1307 and to 1.02 and 1.35 days $^{-1}$ for PG204, respectively. The lag phase of PG204 was significantly increased $(p<0.050)$ in the rest of the confrontations except in the presence of Z. meyerae L29. 
Table 2. Growth parameters ( $\mu$ and lag phase) and percent reduction of mycelia of P. glabrum confronted with selected yeasts for the detection of antifungal of volatile organic compounds (VOCs).

\begin{tabular}{|c|c|c|c|c|c|c|}
\hline \multirow[t]{2}{*}{ Confrontation } & \multicolumn{2}{|c|}{$\left(\mathrm{mm} \mathrm{Day}{ }^{-1}\right)$} & \multicolumn{2}{|c|}{$\begin{array}{l}\text { Lag Phase } \\
\left(\text { Day }^{-1}\right)\end{array}$} & \multicolumn{2}{|c|}{$\begin{array}{l}\% \text { Reduction in } \\
\text { Size of Mycelia } \\
\text { (Day 4) }\end{array}$} \\
\hline & Media & $\mathrm{SD}^{1}$ & Media & SD & Media & SD \\
\hline \multicolumn{7}{|l|}{ Penicillium glabrum 1307} \\
\hline Control & $5.45^{\mathrm{d}, \mathrm{e}, \mathrm{f}, 1}$ & 0.07 & $0.86^{\mathrm{e}, \mathrm{f}}$ & 0.01 & - & - \\
\hline Pichia terricola L14 & $5.77^{\mathrm{a}, \mathrm{b}, \mathrm{c}, \mathrm{d}}$ & 0.29 & $1.52^{\mathrm{a}, \mathrm{b}}$ & 0.19 & $9.17^{\mathrm{b}}$ & 4.00 \\
\hline Pichia kudriavzevii L18 & $4.73^{\mathrm{g}}$ & 0.25 & $1.65^{\mathrm{a}}$ & 0.12 & $31.48^{\mathrm{a}}$ & 2.50 \\
\hline Hormonema viticola L21 & $4.94^{\mathrm{f}, \mathrm{g}}$ & 0.07 & $0.87^{\mathrm{e}, \mathrm{f}}$ & 0.03 & $6.06^{b, c, d}$ & 3.61 \\
\hline Zygoascus meyerae L29 & $5.77^{a, b, c, d}$ & 0.14 & $1.11^{\mathrm{c}, \mathrm{d}, \mathrm{e}}$ & 0.09 & $-0.10^{\mathrm{d}, \mathrm{e}}$ & 5.73 \\
\hline Aureobasidium pullulans L30 & $5.72^{b, c, d}$ & 0.16 & $1.03^{\mathrm{d}, \mathrm{e}}$ & 0.04 & $-1.65^{\mathrm{e}}$ & 3.75 \\
\hline Aureobasidium pullulans L31 & $5.59^{c, d, e}$ & 0.09 & $1.00^{\mathrm{d}, \mathrm{e}}$ & 0.08 & $-2.38^{\mathrm{e}}$ & 2.60 \\
\hline Hanseniaspora uvarum L35 & $5.51^{\mathrm{d}, \mathrm{e}}$ & 0.08 & $1.02^{\mathrm{d}, \mathrm{e}}$ & 0.09 & $1.38^{\mathrm{c}, \mathrm{d}, \mathrm{e}}$ & 6.02 \\
\hline \multicolumn{7}{|l|}{ Penicillium glabrum 204} \\
\hline Control & $5.51^{\mathrm{e}, \mathrm{f}}$ & 0.16 & $0.61^{\mathrm{e}}$ & 0.09 & - & - \\
\hline Pichia terricola L14 & $5.30^{e, f, g}$ & 0.04 & $1.02^{\mathrm{d}, \mathrm{e}}$ & 0.03 & $9.842^{b}$ & 3.34 \\
\hline Pichia kudriavzevii L18 & $5.10^{\mathrm{f}, \mathrm{g}, \mathrm{h}}$ & 0.24 & $1.35^{\mathrm{a}, \mathrm{b}}$ & 0.11 & $23.91^{\mathrm{a}}$ & 1.68 \\
\hline Hormonema viticola L21 & $6.18^{a, b, c}$ & 0.05 & $1.22^{b, c}$ & 0.04 & $11.23^{b}$ & 1.96 \\
\hline Zygoascus meyerae L29 & $5.85^{\mathrm{d}, \mathrm{e}}$ & 0.14 & $0.77^{\mathrm{e}}$ & 0.08 & $2.69^{c, d, e}$ & 3.05 \\
\hline Aureobasidium pullulans L30 & $6.27^{\mathrm{a}, \mathrm{b}}$ & 0.26 & $1.24^{\mathrm{a}, \mathrm{b}, \mathrm{c}}$ & 0.11 & $2.08^{c, d, e}$ & 4.44 \\
\hline Aureobasidium pullulans L31 & $6.08^{a, b, c, d}$ & 0.31 & $\begin{array}{c}1.08 \\
b, c, d, e\end{array}$ & 0.21 & $7.00^{b, c}$ & 2.05 \\
\hline Hanseniaspora uvarum L35 & $6.41^{\mathrm{a}}$ & 0.04 & $1.33^{\mathrm{a}, \mathrm{b}}$ & 0.02 & $7.37^{b, c}$ & 1.95 \\
\hline$p$ & $<0.001$ & & $<0.001$ & & $<0.001$ & \\
\hline
\end{tabular}

${ }^{1}$ statistical deviation. ${ }^{\text {a-h }}$ by columns, media values with different letters indicates significant differences $(p<0.050)$.

Another parameter studied was the reduction of the mycelia diameter (Table 2). At 4 days of confrontation, P. kudriavzevii L18, through VOC production, caused the greatest inhibition of P. glabrum ( $31.48 \pm 2.50 \%$ and $23.91 \pm 1.68 \%$ for PG1307 and PG204, respectively). Pichia terricola L14 and Z. meyerae L21 also significantly reduced the diameter of both strains of molds. Penicillium glabrum 204 was inhibited by A. pullulans L31 and by H. uvarum L35 as well.

The inhibition of spore germination and a reduction in the size of the germ tube by selected yeasts is shown in Table 3. No differences were found in the percentage of spores germinated between both P. glabrum strains with $88.78 \pm 4.03 \%$ for PG1307 and $93.74 \pm 3.93 \%$ for PG204 after $10 \mathrm{~h}$ of incubation. The size of the germ tube was $71.61 \pm 30.50 \mu \mathrm{M}$ for PG1307 and $87.02 \pm 42.20 \mu \mathrm{M}$ for PG204. Pichia terricola L14 was the unique selected yeast that reduced the conidia germination. A significant reduction was obtained for the three concentrations of cells of $P$. terricola L14 assayed, and it was yeast concentration-dependent $(p<0.050)$. In addition, a reduction in the size of the germ tube was observed by confrontation with P. terricola L14 and P. kudriavzevii L18. Germ tubes in these confrontations had around half of the size of the controls. However, no significant influence of yeast cell concentration was observed on germination tube size.

The results for the other mechanisms of antagonism studied (parasitism, antibiosis, production of lytic enzymes, biofilm formation, and competition for nutrients) are shown in Table 4. Weak cell adhesion to P. glabrum hyphae was observed for Z. meyerae L29. The rest of the yeasts did not show the ability to attached to mold cell walls. Different enzymatic activities were observed. Pichia terricola L14 presented $\beta$-glucanase activity. Hormonema viticola L21, Z. meyerae L29, and A. pullulans L30 and L31 presented chitinase, $\beta$-glucanase, and pectinase activity. In addition, both strains of A. pullulans tested displayed proteolytic activity. The screening of biofilm formation in vitro assay showed that the strains P. terricola L14, Z. meyerae L29 and H. uvarum L35 were capable of adhering to the bottom of polystyrene wells and retain crystal violet colorant. 
Table 3. Percentage of germinated spores and size of germ tube $(\mu \mathrm{M})$ in direct contact with selected yeasts.

\begin{tabular}{|c|c|c|c|c|c|c|c|c|c|c|c|c|}
\hline \multirow{3}{*}{ Confrontation } & \multicolumn{6}{|c|}{$\%$ Spores Germinated } & \multicolumn{6}{|c|}{ Size of Germ Tube $(\mu \mathrm{M})$} \\
\hline & \multicolumn{2}{|c|}{$10^{5}$ Cell mL $^{-1}$} & \multicolumn{2}{|c|}{$10^{6}{\mathrm{Cell} \mathrm{mL}^{-1}}^{-1}$} & \multicolumn{2}{|c|}{$10^{7}$ Cell mL $^{-1}$} & \multicolumn{2}{|c|}{$10^{5}$ Cell $\mathrm{mL}^{-1}$} & \multicolumn{2}{|c|}{$10^{6} \mathrm{Cell} \mathrm{mL}^{-1}$} & \multicolumn{2}{|c|}{$10^{7}{\text { Cell } \mathrm{mL}^{-1}}^{-1}$} \\
\hline & Media & $\mathrm{SD}^{1}$ & Media & SD & Media & SD & Media & SD & Media & SD & Media & SD \\
\hline \multicolumn{13}{|l|}{ Penicillium glabrum 1307} \\
\hline Control & & & 88.78 & 4.03 & & & & & 71.61 & 30.50 & & \\
\hline Pichia terricola L14 & $77.45 *$ & 5.32 & $65.97 *$ & 8.68 & $64.88^{*}$ & 5.25 & $35.13 *$ & 12.42 & $26.06^{*}$ & 9.088 & $27.93 *$ & 7.16 \\
\hline Pichia kudriavzevii L18 & 77.31 & 10.60 & 81.72 & 3.91 & 81.04 & 6.46 & $38.26^{*}$ & 11.31 & $34.20 *$ & 17.61 & 35.13 * & 14.70 \\
\hline Hormonema viticola L21 & 91.28 & 6.58 & 93.44 & 5.10 & 92.52 & 5.01 & 74.23 & 32.42 & 85.73 & 37.72 & 68.46 & 37.55 \\
\hline Zygoascus meyerae L29 & 93.22 & 4.36 & 93.87 & 4.10 & 94.36 & 3.75 & 77.13 & 28.73 & 73.53 & 36.32 & 73.82 & 36.33 \\
\hline Aureobasidium pullulans L30 & 90.93 & 3.89 & 92.49 & 4.90 & 91.56 & 5.78 & 84.20 & 38.48 & 73.46 & 33.67 & 80.27 & 37.05 \\
\hline Aureobasidium pullulans L31 & 93.61 & 1.83 & 93.59 & 4.23 & 87.53 & 3.92 & 67.60 & 24.58 & 66.26 & 15.10 & 61.66 & 22.46 \\
\hline Hanseniaspora uvarum L35 & 94.13 & 0.61 & 91.48 & 4.88 & 92.18 & 5.53 & 72.40 & 28.96 & 77.49 & 27.99 & 76.46 & 18.67 \\
\hline \multicolumn{13}{|l|}{ Penicillium glabrum 204} \\
\hline Control & & & 93.74 & 3.93 & & & & & 87.02 & 42.20 & & \\
\hline Pichia terricola L14 & $75.50 *$ & 3.42 & $70.84^{*}$ & 2.82 & $63.61 *$ & 7.28 & $36.46^{*}$ & 12.40 & $29.46^{*}$ & 17.53 & $29.13 *$ & 15.45 \\
\hline Pichia kudriavzevii L18 & 87.02 & 2.68 & 88.25 & 3.16 & 90.54 & 6.12 & 48.40 * & 20.20 & $42.40 *$ & 24.23 & 37.33 * & 18.18 \\
\hline Hormonema viticola L21 & 93.44 & 4.87 & 90.68 & 3.24 & 89.65 & 3.84 & 76.46 & 24.73 & 84.02 & 30.53 & 62.93 & 29.32 \\
\hline Zygoascus meyerae L29 & 90.84 & 4.46 & 89.56 & 5.91 & 89.69 & 3.84 & 63.66 & 27.15 & 66.06 & 22.90 & 66.61 & 17.12 \\
\hline Aureobasidium pullulans L30 & 86.71 & 5.87 & 90.67 & 4.70 & 88.58 & 4.75 & 101.2 & 15.86 & 72.26 & 26.35 & 64.13 & 20.53 \\
\hline Aureobasidium pullulans L31 & 92.74 & 7.21 & 88.28 & 4.58 & 84.35 & 10.50 & 65.66 & 25.76 & 69.01 & 28.62 & 80.66 & 24.07 \\
\hline Hanseniaspora uvarum L35 & 97.89 & 2.88 & 95.69 & 4.23 & 92.08 & 5.96 & 71.13 & 29.59 & 62.42 & 22.52 & 64.06 & 15.91 \\
\hline$p$ & $<0.001$ & & $<0.001$ & & $<0.001$ & & $<0.001$ & & $<0.001$ & & $<0.001$ & \\
\hline
\end{tabular}


Table 4. Assays for characterization of biocontrol mechanism.

\begin{tabular}{|c|c|c|c|c|c|c|c|c|c|}
\hline \multirow[t]{2}{*}{ Strain. } & \multirow[t]{2}{*}{ Parasitism } & \multirow[t]{2}{*}{ Antibiosis } & \multicolumn{4}{|c|}{ Enzymatic Activities } & \multirow[t]{2}{*}{$\begin{array}{c}\text { Biofilm } \\
\text { Formation }\end{array}$} & \multicolumn{2}{|c|}{ Competition for Nutrients } \\
\hline & & & Chitinase & $\beta$-Glucanase & Pectinase & Protease & & $\begin{array}{c}\text { Iron } \\
\text { Depletion }\end{array}$ & $\begin{array}{c}\text { In Vivo } \\
\text { Competition }\end{array}$ \\
\hline Pichia terricola L14 & - & - & - & + & - & - & + & - & + \\
\hline Pichia kudriavzevii L18 & - & - & - & - & - & - & - & - & - \\
\hline Hormonema viticola L21 & - & - & + & + & + & - & - & - & - \\
\hline Zygoascus meyerae L29 & - & - & + & + & + & - & + & - & - \\
\hline Aureobasidium pullulans L30 & - & - & + & + & + & + & - & - & - \\
\hline Aureobasidium pullulans L31 & - & - & + & + & + & + & - & - & - \\
\hline Hanseniaspora uvarum L35 & - & - & - & - & - & - & + & - & - \\
\hline
\end{tabular}


The iron competition was not the mechanism of any selected yeast in this study (Table 4). On grapes, the capacity for control of P. terricola L14 was reduced when YNB broth was added to the wound. All grapes presented mycelia development of $P$. glabrum after 3 days of storage when nutrients were artificially added, whereas around $10 \%$ of grapes presented symptoms of $P$. glabrum development without nutrient addition. Hence, competition for nutrients can be associated with this yeast strain. However, the rest of the yeasts confronted with P. glabrum in wounded grapes did not reduce $(p<0.050)$ their control capability when extra nutrients were present in the environment.

\subsection{In Vivo Assay on Wounded Grapes}

Control wounded grapes infected with P. glabrum strains PG137 and PG204 showed that the incidence of both strains was similar (PG1307, Figure 3A; PG204, Figure 3B). However, PG1307 was more infective $(p<0.050)$, achieving 100\% of incidence after 6 days of inoculation, whereas this happened at 9 days with PG204. The confrontation of molds with the selected yeasts gave some surprising results. Yeasts without a priori antagonistic properties according to direct confrontation assay significantly reduced the incidence of $P$. glabrum on grapes and vice versa. Yeasts selected as neutral or "negative controls" such as P. kudriavzevii L18, H. viticola L21, and H. uvarum L35 reduced $(p<0.050)$ the incidence of P. glabrum to $0 \%, \sim 50 \%$, and $\sim 33 \%$, respectively, at 9 days of confrontation. On the contrary, A. pullulans isolates did not reduce the incidence of molds, despite the fact that they were selected due to their control of mold growth in PDA plates. The other preselected antagonistic yeasts, P. terricola L14 and Z. meyerae L29 reduced the incidence of P. glabrum to $\sim 13 \%$ and $\sim 25 \%$, respectively. Figure $3 \mathrm{~A}, \mathrm{~B}$ reflect the observation of mycelia development on wounds. However, the visual appearance of grapes inoculated with selected yeast excluded several of them as potential biocontrol agents. Pichia terricola L14 completely turned grapes to a brown color, as the pictures in Figure 3 show. Hormonema viticola, a "black yeast" [56], produced blackening of the wounds. In addition, H. uvarum L35 produced browning and depression of the wounds. The control without inoculation of molds confirmed the spoiling capacity of these three yeast isolates. 

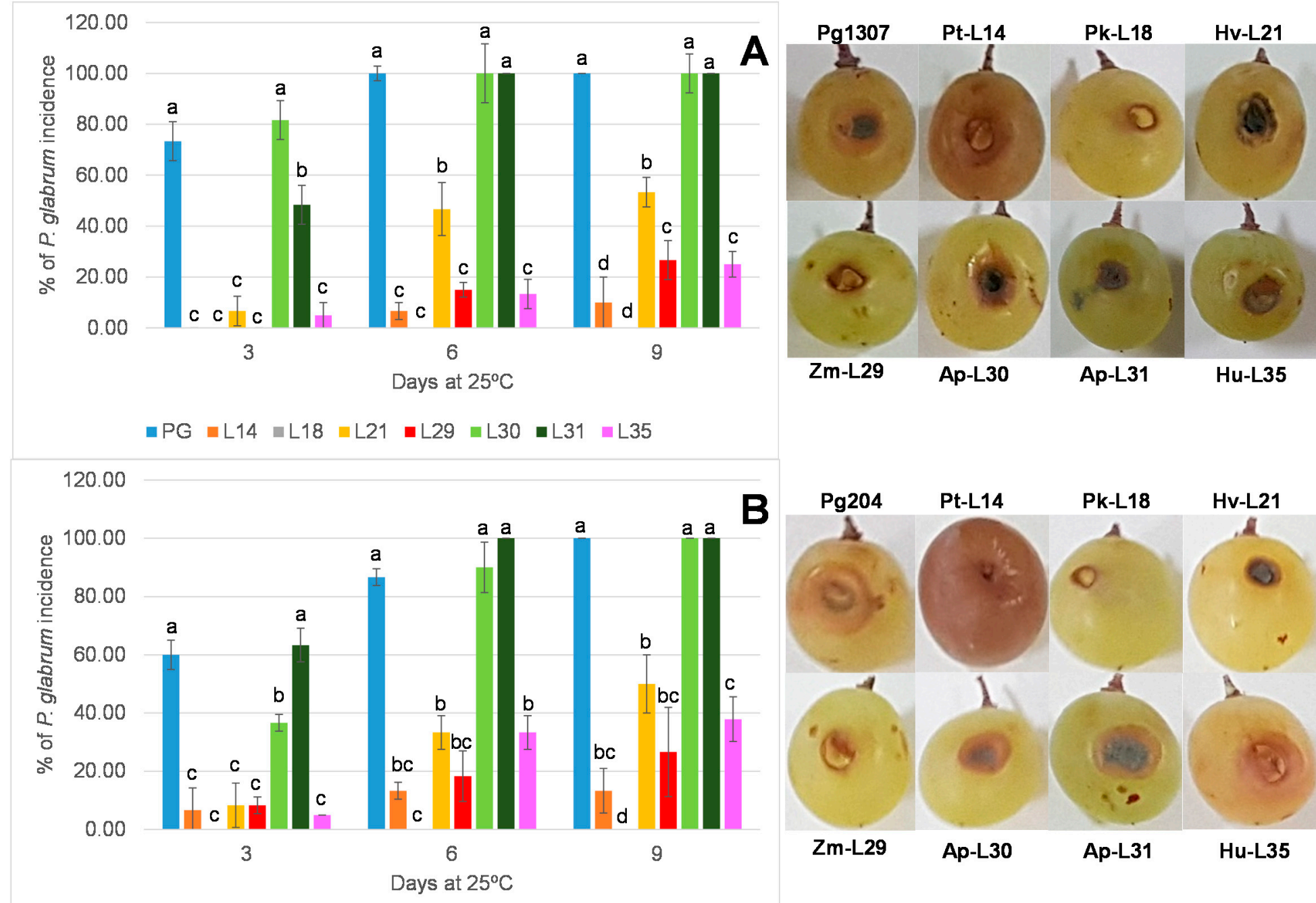

Figure 3. Percentage of disease incidence and symptoms of confrontations on wounded grapes at $25{ }^{\circ} \mathrm{C}$ among P. glabrum M1307 (A), M204 (B), and the yeast isolates P. terricola L14, P. kudriavzevii L18, H. viticola L21, Z. meyerae L29, A. pullulans L30 and L31, and H. uvarum L35. Different letters indicate statistical differences ( $p<0.050)$ in each sampling day. 


\section{Discussion}

The yeast populations of grapes vary depending on practices, vectors, climate, geographical area, maturity state, etc. [1]. Although controversial, results and hypotheses about the influence of these factors in microbial populations are shown in the literature. Thus, great differences in yeast populations have been registered in previous works. Settanni et al. [57] reported high counts of yeasts in grapes from the Marsala wine area (Italy) with values that ranged from 3.54 to $6.92 \log _{10} \mathrm{CFU} / \mathrm{g}$, which agreed with the yeast population found in the present work. In contrast, lower counts $\left(10^{2}\right.$ to $10^{4} \log _{10}$ CFU/g) of yeasts in healthy grapes from Texas (USA) were reported by Bougreau et al. [58]. Damaged grapes gave higher counts of yeasts than healthy grapes from Attica (Greece), according to Nisiotou and Nychas [59] and from Trento, Italy [60]; these are in contrast with the results obtained in the present work.

In this work, six different yeast species were identified; A. pullulans and Pichia spp. were predominant. Similar species biodiversity was detected by Cordero-Bueso et al. [54], who found seven, six, and five different species from conventional, organic, and biodynamical vineyards, respectively. In this case, $A$. pullulans and H. uvarum were the dominant species. In the same sense, Drumonde-Neves et al. [61] found that human activities increased yeast biodiversity. They described a total of 23 different species dominated by H. uvarum (66\% of isolates) and P. terricola (11\%) in different vineyards from Azores Archipelago, being the maximum diversity per vineyard of 11 yeast species. Other works have found more richness of species in vineyards with different farming systems [1], with between 9 and 17 different yeast species; however, that analysis included samples from different parts of the plant. Climate is another factor that defines yeasts biodiversity. Lobón (Badajoz, Spain) belongs to a climatic area with media temperatures in the summer around $30^{\circ} \mathrm{C}$ and very scarce rainfall $(471 \mathrm{~mm})$. Rainfall levels could be associated with biodiversity and patterns of yeasts species as reported by Castrillo et al. [62] of grapes from four different areas (Denominations of Origen, DO) of Galicia (Spain). The driest area, DO Monterrey $(595 \mathrm{~mm})$, presented lower species richness, dominated by A. pullulans, than DO Rias Baixas (1071 mm), dominated by H. uvarum. Likewise, the number of yeast species was increased in two Spanish wine zones with both Atlantic and interior climate in a rainy year [63]. Poor sanitary conditions and increased of damaged grapes by cracking could favor the biodiversity of yeasts, especially of oxidative species. In any case, rainy or usual year, yeast biodiversity was greater than our number of yeast species, with 21 and 28 species. In contrast, a reduction of yeast biodiversity was observed with a precipitations increase [61], which could have an effect of washing away yeasts from grapes skin.

Mold populations are frequently dominated by Alternaria, Aspergillus, Cladosporium, Botrytis, and Penicillium members, although this is also variable depending on the studies. Factors as varieties, climate and cultural practices influence filamentous fungi populations. Alternaria, Botrytis, and Cladosporium were the genera more frequently identified in grapes from regions of Alentejo, Douro, Ribatejo, and Vinhos Verdes in Portugal [21], with climatic conditions similar to those of the present work (Mediterranean climate Csa and Csb according to Köppen climate classification). Serra et al. [21] reported that Aspergillus prevalence was dependent on climate, whereas the genus Penicillium occurrence was not influenced by climatic conditions. García-Cela et al. [64] showed that Aspergillus and Alternaria were the dominant genera isolated from Spanish vineyards (Csa according to Köppen climate classification), whereas Penicillium isolates represented less than $4 \%$ of isolates. In agreement with our results, Penicillium was the dominant genus (above $50 \%$ of identifications) of molds in grapes from the Burgundy area, with an oceanic climate, in France [4]. Nevertheless, Penicillium and Aspergillus shared the dominance (50\% of identifications) on grapes from 5 regions of France with Oceanic climates ( $\mathrm{Cfb}$ ) such as Alsace, Beaujolais, Côtes du Rhône, Languedoc, and Bordelais [2].

The efforts to control the mold population in vineyards are usually directed to B. cinerea [6,36,65], Alternaria alternaria [66], mycotoxigenic species of Aspergillus section Nigri [41,67], and P. expansum $[44,46]$. However, the relevance of other species in the pathogenesis and spoilage of grapes deserves attention [5,47]). In the present work, Alternaria, Cladosporium, and Aspergillus 
isolates were identified in spoiled grapes, but $P$. glabrum was the most frequent species identified in several bunches with symptoms of Penicillium development, where it was the unique species identified. Genetic characterization of $P$. glabrum isolates allowed the identification of two different strains.

In this work, the direct confrontation in plates of PDA among two P. glabrum strains and yeasts gave different types of interactions. Inhibitory effects were observed in seven out of 18 isolates of P. terricola and one isolate of A. pullulans (Figure 2E,F). The strain dependence of biocontrol abilities is in agreement with previous findings of isolates of I. terricola (synonymous with P. terricola) and H. uvarum against B. cinerea [60]. Antagonistic activity of strains belonging to I. terricola and A. pullulans isolated from vineyards has been reported against different pathogens such as A. carbonarius and A. niger [41,67]; B. cinerea [60] and Greeneria uvicola, which is responsible for bitter rot [68]. Other isolates such as A. pullulans L30 (Figure 2C) and Z. meyerae modified the visual appearance of P. glabrum (Figure 2D). The other species of yeasts identified did not show remarkable effects on P. glabrum development or even those completely covered by mycelia, despite members of $H$. uvarum and P. kudriavzevii being previously described as biocontrol agents [52,69]. Moreover, no relevant differences were found in the interactions among yeasts and the two strains of P. glabrum evaluated (M1307 and M204). However, in vitro screening of antagonist activity presented disagreement with results obtained in the in vivo assay of wounded grapes (Figures 2 and 3). Yeasts selected as having neutral activity by direct confrontation, P. kudriavzevii L18 and H. uvarum L35, displayed a remarkable antagonist activity on grapes. Hence, these results suggest that combined strategies must be applied for properly screening antagonist activity.

The inquiry for the possible mechanism of action of selected yeasts showed that the production of antifungal VOCs on PDA plates and its consequent effect on P. glabrum growth was a common characteristic in the selected yeasts except for Z. meyerae L29, which was without any effect on growth rates, lag phase, and reduction of mycelia diameter. The rest of the yeasts were primarily affected by the lag phase delay, especially to P. glabrum M204. Figure 4 shows the volatile compounds associated with yeast development. Acids were found in P. terricola L14 confrontations, branched and aromatic alcohols in H. viticola, H. uvarum, A. pullulans and P. kudriavzevii confrontations, and esters were associated with P. kudriavzevii L18 growth. This last yeast, a producer of branched and aromatic alcohols and their esters, presented the greatest influence on P. glabrum growth, which is in agreement with the results obtained by Choińska et al. [69]. Esters such as n-propyl acetate, isoamyl acetate, benzyl acetate, and 2-phenethyl acetate have been associated with B. cinerea control [52]. Although P. kudriavzevii L18 was previously selected in the direct confrontation as a negative control, this isolate was the most effective antagonist against $P$. glabrum in the in vivo assays. These results pointed out that direct confrontation is not a proper screening method to identify antagonist yeast producers of antifungal VOCs.

Regarding spore germination, the two isolates of the Pichia genus reduced the size of the germ tube of P. glabrum, and P. terricola L14 also inhibited spore germination. This fact could be associated with space colonization, as this was observed in direct confrontation (Figure 2E), whereas reduction of the germ tube size by P. kudriavzevii L18 could be associated with antifungal VOC production [70]. The rest of the yeasts did not modify the spore germination.

Concerning the other possible mechanisms of action studied, no parasitism of yeast cells to P. glabrum hyphae was observed in most of the selected yeast. A slight attachment of cells of Z. meyerae L29 was observed against both strains of molds. Previous studies have proved that the capacity of parasite fungal hyphae is related to the production of lytic enzymes [71]. In this case, chitinase, $\beta$-glucanase, and pectinase activity were detected for Z. meyerae L29. However, other yeasts with the three hydrolytic capabilities were not related with attachment to fungal hyphae as well as the protease activity shown by A. pullulans isolated L30 and L31. Moreover, the results of the in vivo assays reveal that enzymatic activities could not be a key mechanism on fruit surfaces. No antibiosis activities were detected in any yeasts either. 


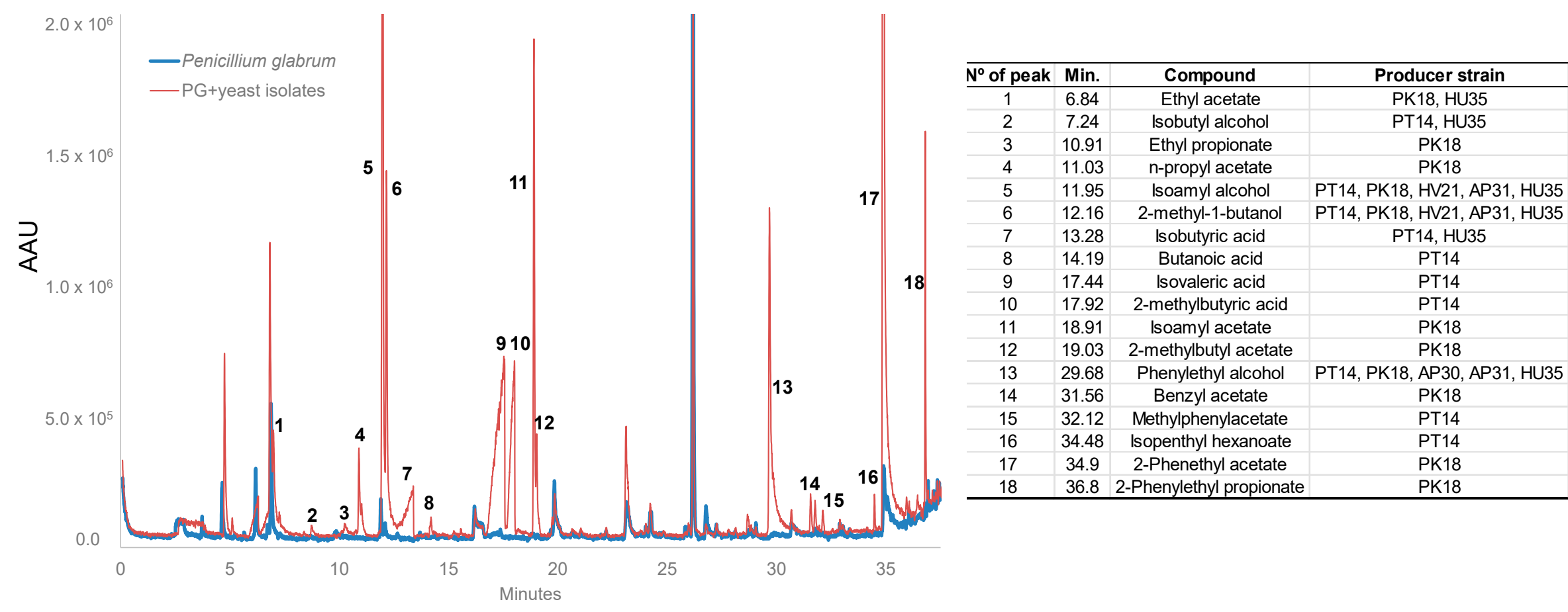

Figure 4. Representative profile of volatile compounds into the double dish systems control (P. glabrum, blue line) and confrontations ( . glabrum + yeasts; red line).

Numbers indicate compounds associated with yeast growth. The table relates the number of peaks, retention times, and identification of compounds (by NIST database, Kovats index) from the producer yeasts. 
Previous work highlighted the importance of biofilm formation on the biocontrol activity of yeast $[27,72]$, although this remains one of the least known mechanisms of antagonism. Three yeasts, P. terricola L14, Z. meyerae L29, and H. uvarum L35, formed biofilm in vitro assays. This capability has been related to wound colonization in fruits [55]. Our preliminary results showed that biofilm could be involved in the biocontrol of $H$. uvarum L35, which presented remarkable reductions of disease incidence in wounded grapes. However, other mechanisms as the induction of resistance in host tissues $[73,74]$ could be associated with a reduction of disease development by H. uvarum L35.

The competition for nutrients is another relevant mechanism of biological control. In our study, iron presence did modify the antagonism action on selected yeast. The enrichment of grape wounds with YNB increased the incidence of P. glabrum (from $~ 10 \%$ infections to $~ 90 \%$ of inoculated grapes) in confrontations with P. terricola L14, proving that this yeast bases its antagonism on the competition for nutrients more than biofilm formation. Using the same methodology, Ruiz-Moyano et al. [53] showed that Metschnikowia pulcherrima L672 based its mechanism on the competition for nutrients.

Finally, characterization of the mechanisms of antagonism explained, at least partially, the results obtained in the inoculation of wounded grapes, where five yeasts efficiently reduced the infection of P. glabrum (Figure 3). Other mechanisms may be involved; so, further research is needed to clarify them.

\section{Conclusions}

During development in vineyards and subsequent processes and commercialization, grapes are infected by different pathogenic molds. In this work, P. glabrum was the dominant mold in spoiled bunches.

To control the infections and spoilage by P. glabrum, a screening of potential antagonistic yeasts was performed. Five yeasts, P. terricola L14, Z. meyerae L29, P. kudriavzevii L18, H. viticola L21, and H. uvarum L35, efficiently reduced the infection of $P$. glabrum on wounded grapes, although $P$. terricola, $H$. viticola and $H$. uvarum themselves triggered different symptoms of alteration on grapes. Different mechanisms, such as the production of VOCs, secretion of lytic enzymes, biofilm formation, and competition for nutrients, were involved in biocontrol. Finally, the isolated P. kudriavzevii L18 (a producer of antifungal VOCs) and Z. meyerae L29 (with chitinase, $\beta$-glucanase and pectinase activities and a producer of in vitro biofilm) are proposed as biocontrol agents in vineyards and during the commercialization of grapes. To our knowledge, this is the first report about the potential of $Z$. meyerae as a biocontrol agent.

Author Contributions: All of the authors contributed significantly to the research. A.H. was the principal investigator involved with project design. C.M.C., A.M. (Ana Martínez), P.T., S.R.-M., and M.V.-H. contributed to the experimental work. A.H., S.R.-M., and A.M. (Alberto Martín) contributed to the data analysis. A.H. contributed to writing the original draft of the manuscript. S.R.-M. and A.M. (Ana Martínez) contributed the review and edited the manuscript. A.H. and A.M. (Ana Martínez) contributed to the acquisition of funding. All authors have read and agreed to the published version of the manuscript.

Funding: This research received no external funding.

Acknowledgments: This work was supported by the Ministry of Science, Innovation and Universities of Spain (RTI2018-096882-B-I00) and the Extremadura Government (GR18165).

Conflicts of Interest: The authors declare no conflict of interest.

\section{References}

1. Setati, M.E.; Jacobson, D.; Andong, U.-C.; Bauer, F.F. The Vineyard Yeast Microbiome, a Mixed Model Microbial Map. PLoS ONE 2012, 7, e52609. [CrossRef] [PubMed]

2. Sage, L.; Garon, D.; Seigle-Murandi, F. Fungal Microflora and Ochratoxin A Risk in French Vineyards. J. Agric. Food Chem. 2004, 52, 5764-5768. [CrossRef]

3. Schmid, F.; Moser, G.; Müller, H.; Berg, G. Functional and Structural Microbial Diversity in Organic and Conventional Viticulture: Organic Farming Benefits Natural Biocontrol Agents. Appl. Environ. Microbiol. 2011, 77, 2188-2191. [CrossRef] [PubMed] 
4. Diguta, C.; Vincent, B.; Guilloux-Benatier, M.; Alexandre, H.; Rousseaux, S. PCR ITS-RFLP: A useful method for identifying filamentous fungi isolates on grapes. Food Microbiol. 2011, 28, 1145-1154. [CrossRef] [PubMed]

5. Rousseaux, S.; Diguta, C.F.; Radoï-Matei, F.; Alexandre, H.; Guilloux-Benatier, M. Non-Botrytis grape-rotting fungi responsible for earthy and moldy off-flavors and mycotoxins. Food Microbiol. 2014, 38, 104-121. [CrossRef] [PubMed]

6. Rabosto, X.; Carrau, M.; Paz, A.; Boido, E.; Dellacassa, E.; Carrau, F.M. Grapes and vineyard soils as sources of microorganisms for biological control of Botrytis cinerea. Am. J. Enol. Vitic. 2006, 57, 332-338.

7. Wang, X.; Glawe, D.A.; Kramer, E.; Weller, D.M.; Okubara, P.A. Biological Control of Botrytis cinerea: Interactions with Native Vineyard Yeasts from Washington State. Phytopathology 2018, 108, 691-701. [CrossRef]

8. Jacometti, M.; Wratten, S.D.; Walter, M. Review: Alternatives to synthetic fungicides for Botrytis cinerea management in vineyards. Aust. J. Grape Wine Res. 2010, 16, 154-172. [CrossRef]

9. Ky, I.; Lorrain, B.; Jourdes, M.; Pasquier, G.; Fermaud, M.; Gény, L.; Rey, P.; Doneche, B.; Teissedre, P.-L. Assessment of grey mould (Botrytis cinerea) impact on phenolic and sensory quality of Bordeaux grapes, musts and wines for two consecutive vintages. Aust. J. Grape Wine Res. 2012, 18, 215-226. [CrossRef]

10. Morales, H.; Silva, L.; Paterson, R.R.M.; Venâncio, A.; Lima, N. Effects of the origins of Botrytis cinerea on earthy aromas from grape broth media further inoculated with Penicillium expansum. Food Microbiol. 2011, 28, 1048-1053. [CrossRef]

11. Tjamos, S.E.; Antoniou, P.P.; Kazantzidou, A.; Antonopoulos, D.F.; Papageorgiou, I.; Tjamos, E.C. Aspergillus niger and Aspergillus carbonarius in Corinth Raisin and Wine-Producing Vineyards in Greece: Population Composition, Ochratoxin A Production and Chemical Control. J. Phytopathol. 2004, 152, 250-255. [CrossRef]

12. Garcia-Cela, E.; Crespo-Sempere, A.; Ramos, A.; Sanchis, V.; Marin, S. Ecophysiological characterization of Aspergillus carbonarius, Aspergillus tubingensis and Aspergillus niger isolated from grapes in Spanish vineyards. Int. J. Food Microbiol. 2014, 173, 89-98. [CrossRef] [PubMed]

13. Covarelli, L.; Beccari, G.; Marini, A.; Tosi, L. A review on the occurrence and control of ochratoxigenic fungal species and ochratoxin A in dehydrated grapes, non-fortified dessert wines and dried vine fruit in the Mediterranean area. Food Control 2012, 26, 347-356. [CrossRef]

14. Jiang, C.; Shi, J.; Zhu, C. Fruit spoilage and ochratoxin a production by Aspergillus carbonarius in the berries of different grape cultivars. Food Control 2013, 30, 93-100. [CrossRef]

15. Dachery, B.; Hernandes, K.C.; Veras, F.F.; Schmidt, L.; Augusti, P.R.; Manfroi, V.; Zini, C.A.; Welke, J.E. Effect of Aspergillus carbonarius on ochratoxin a levels, volatile profile and antioxidant activity of the grapes and respective wines. Food Res. Int. 2019, 126, 108687. [CrossRef] [PubMed]

16. Ostry, V.; Malir, F.; Cumova, M.; Kyrova, V.; Toman, J.; Grosse, Y.; Pospichalova, M.; Ruprich, J. Investigation of patulin and citrinin in grape must and wine from grapes naturally contaminated by strains of Penicillium expansum. Food Chem. Toxicol. 2018, 118, 805-811. [CrossRef]

17. Abdullah, Q.; Mahmoud, A.; Al-harethi, A. Isolation and identification of fungal post-harvest rot of some fruits in Yemen. PSM Microbiol. 2016, 1, 36-44.

18. Lorenzini, M.; Simonato, B.; Favati, F.; Bernardi, P.; Sbarbati, A.; Zapparoli, G. Filamentous fungi associated with natural infection of noble rot on withered grapes. Int. J. Food Microbiol. 2018, 272, 83-86. [CrossRef]

19. Bau, M.; Bragulat, M.R.; Abarca, M.L.; Minguez, S.; Cabañes, F.J. Ochratoxigenic species from Spanish wine grapes. Int. J. Food Microbiol. 2005, 98, 125-130. [CrossRef]

20. Freire, L.; Passamani, F.R.F.; Thomas, A.B.; Nassur, R.D.C.M.R.; Silva, L.M.; Paschoal, F.N.; Pereira, G.E.; Prado, G.; Batista, L.R. Influence of physical and chemical characteristics of wine grapes on the incidence of Penicillium and Aspergillus fungi in grapes and ochratoxin A in wines. Int. J. Food Microbiol. 2017, 241, 181-190. [CrossRef]

21. Serra, R.; Lourenço, A.M.G.; Alípio, P.; Venâncio, A. Influence of the region of origin on the mycobiota of grapes with emphasis on Aspergillus and Penicillium species. Mycol. Res. 2006, 110, 971-978. [CrossRef] [PubMed]

22. Börjesson, T.S.; Stöllman, U.M.; Schnürer, J.L. Off-odorous compounds produced by molds on oatmeal agar: Identification and relation to other growth characteristics. J. Agric. Food Chem. 1993, 41, 2104-2111. [CrossRef]

23. Börjesson, T.; Stöllman, U.; Schnürer, J. Volatile metabolites produced by six fungal species compared with other indicators of fungal growth on cereal grains. Appl. Environ. Microbiol. 1992, 58, 2599-2605. [CrossRef] [PubMed] 
24. Bardas, G.A.; Tzelepis, G.D.; Lotos, L.; Karaoglanidis, G.S. First report of Penicillium glabrum causing fruit rot of pomegranate (Punica granatum) in Greece. Plant Dis. 2009, 93, 1347. [CrossRef] [PubMed]

25. Spadaro, D.; Amatulli, M.T.; Garibaldi, A.; Gullino, M.L. First Report of Penicillium glabrum Causing a Postharvest Fruit Rot of Pomegranate (Punica granatum) in the Piedmont Region of Italy. Plant Dis. 2010, 94, 1066. [CrossRef] [PubMed]

26. Duduk, N.; Lazarević, M.; Žebeljan, A.; Vasić, M.; Vico, I. Blue mould decay of stored onion bulbs caused by Penicillium polonicum, P. glabrum and P. expansum. J. Phytopathol. 2017, 165, 662-669. [CrossRef]

27. Spadaro, D.; Droby, S. Development of biocontrol products for postharvest diseases of fruit: The importance of elucidating the mechanisms of action of yeast antagonists. Trends Food Sci. Technol. 2016, 47, 39-49. [CrossRef]

28. Hahn, M. The rising threat of fungicide resistance in plant pathogenic fungi: Botrytis as a case study. J. Chem. Biol. 2014, 7, 133-141. [CrossRef]

29. Li, H.X.; Xiao, C.L. Characterization of Fludioxonil-Resistant and Pyrimethanil-Resistant Phenotypes of Penicillium expansum from Apple. Phytopathology 2008, 98, 427-435. [CrossRef]

30. Bowyer, P.; Denning, D.W. Environmental fungicides and triazole resistance in Aspergillus. Pest Manag. Sci. 2014, 70, 173-178. [CrossRef]

31. Tripathi, P.; Dubey, N. Exploitation of natural products as an alternative strategy to control postharvest fungal rotting of fruit and vegetables. Postharvest Biol. Technol. 2004, 32, 235-245. [CrossRef]

32. Droby, S.; Wisniewski, M.; Macarisin, D.; Wilson, C. Twenty years of postharvest biocontrol research: Is it time for a new paradigm? Postharvest Biol. Technol. 2009, 52, 137-145. [CrossRef]

33. Gasser, F.; Berg, G.; Cardinale, M.; Schildberger, B. Biocontrol of Botrytis cinerea by successful introduction of Pantoea ananatis in the grapevine phyllosphere. Int. J. Wine Res. 2012, 4, 53. [CrossRef]

34. Magnin-Robert, M.; Quantinet, D.; Couderchet, M.; Aziz, A.; Trotel-Aziz, P. Differential induction of grapevine resistance and defense reactions against Botrytis cinerea by bacterial mixtures in vineyards. BioControl 2012, 58, 117-131. [CrossRef]

35. Lemos, W.J.; Bovo, B.; Nadai, C.; Crosato, G.; Carlot, M.; Favaron, F.; Giacomini, A.; Corich, V. Biocontrol Ability and Action Mechanism of Starmerella bacillaris (Synonym Candida zemplinina) Isolated from Wine Musts against Gray Mold Disease Agent Botrytis cinerea on Grape and Their Effects on Alcoholic Fermentation. Front. Microbiol. 2016, 7, 1249. [CrossRef]

36. Pertot, I.; Giovannini, O.; Benanchi, M.; Caffi, T.; Rossi, V.; Mugnai, L. Combining biocontrol agents with different mechanisms of action in a strategy to control Botrytis cinerea on grapevine. Crop. Prot. 2017, 97, 85-93. [CrossRef]

37. Arfaoui, M.; Vallance, J.; Bruez, E.; Rezgui, A.; Melki, I.; Chebil, S.; Sadfi-Zouaouia, N.; Rey, P. Isolation, identification and in vitro characterization of grapevine rhizobacteria to control ochratoxigenic Aspergillus spp. on grapes. Biol. Control 2019, 129, 201-211. [CrossRef]

38. Lappa, I.K.; Mparampouti, S.; Lanza, B.; Panagou, E.Z. Control of Aspergillus carbonarius in grape berries by Lactobacillus plantarum: A phenotypic and gene transcription study. Int. J. Food Microbiol. 2018, 275, 56-65. [CrossRef]

39. Apaliya, M.T.; Zhang, H.; Zheng, X.; Yang, Q.; Mahunu, G.K.; Kwaw, E. Exogenous trehalose enhanced the biocontrol efficacy of Hanseniaspora uvarum against grape berry rots caused by Aspergillus tubingensis and Penicillium commune. J. Sci. Food Agric. 2018, 98, 4665-4672. [CrossRef]

40. De Curtis, F.; De Felice, D.; Ianiri, G.; De Cicco, V.; Castoria, R. Environmental factors affect the activity of biocontrol agents against ochratoxigenic Aspergillus carbonarius on wine grape. Int. J. Food Microbiol. 2012, 159, 17-24. [CrossRef]

41. Dimakopoulou, M.; Tjamos, S.E.; Antoniou, P.P.; Pietri, A.; Battilani, P.; Avramidis, N.; Markakis, E.A.; Tjamos, E.C. Phyllosphere grapevine yeast Aureobasidium pullulans reduces Aspergillus carbonarius (sour rot) incidence in wine-producing vineyards in Greece. Biol. Control 2008, 46, 158-165. [CrossRef]

42. Ponsone, M.L.; Chiotta, M.L.; Combina, M.; Dalcero, A.; Chulze, S. Biocontrol as a strategy to reduce the impact of ochratoxin A and Aspergillus section Nigri in grapes. Int. J. Food Microbiol. 2011, 151, 70-77. [CrossRef] [PubMed]

43. Zahavi, T.; Cohen, L.; Weiss, B.; Schena, L.; Daus, A.; Kaplunov, T.; Zutkhi, J.; Ben-Arie, R.; Droby, S. Biological control of Botrytis, Aspergillus and Rhizopus rots on table and wine grapes in Israel. Postharvest Biol. Technol. 2000, 20, 115-124. [CrossRef] 
44. Assaf, L.R.; Pedrozo, L.P.; Nally, M.C.; Pesce, V.M.; Toro, M.E.; de Figueroa, L.C.; Vazquez, F. Use of yeasts from different environments for the control of Penicillium expansum on table grapes at storage temperature. Int. J. Food Microbiol. 2020, 320, 108520. [CrossRef] [PubMed]

45. Diguța, C.F.; Matei, F.; Cornea, C.P. Biocontrol perspectives of Aspergillus carbonarius, Botrytis cinerea and Pencillium expansum on grapes using epiphytic bacteria isolated from Romanian vineyards. Rom. Biotechnol. Lett. 2016, 21, 11126-11132.

46. Godana, E.A.; Yang, Q.; Wang, K.; Zhang, H.; Zhang, X.; Zhao, L.; Abdelhai, M.H.; Legrand, N.N.G. Bio-control activity of Pichia anomala supplemented with chitosan against Penicillium expansum in postharvest grapes and its possible inhibition mechanism. LWT 2020, 124, 109188. [CrossRef]

47. Droby, S.; Vinokur, V.; Weiss, B.; Cohen, L.; Daus, A.; Goldschmidt, E.E.; Porat, R. Induction of Resistance to Penicillium digitatum in Grapefruit by the Yeast Biocontrol Agent Candida oleophila. Phytopathology 2002, 92, 393-399. [CrossRef]

48. Gallardo, G.; Ruiz-Moyano, S.; Hernández, A.; Benito, M.J.; Córdoba, J.J.; Pérez-Nevado, F.; Martín, A. Application of ISSR-PCR for rapid strain typing of Debaryomyces hansenii isolated from dry-cured Iberian ham. Food Microbiol. 2014, 42, 205-211. [CrossRef]

49. White, T.J.; Bruns, T.; Lee, S.J.; Taylor, J. 38-Amplification and direct sequencing of fungal ribosomal RNA genes for phylogenetics. In PCR Protocols: A Guide to Methods and Applications; Innis, M.A., Gelfand, D.H., Sninsky, J.J., White, T.J., Eds.; Academic Press: Cambridge, MA, USA, 1990; pp. 315-322.

50. Glass, N.L.; Donaldson, G.C. Development of primer sets designed for use with the PCR to amplify conserved genes from filamentous ascomycetes. Appl. Environ. Microbiol. 1995, 61, 1323-1330. [CrossRef]

51. Hong, S.-B.; Go, S.-J.; Shin, H.-D.; Frisvad, J.C.; Samson, R.A. Polyphasic taxonomy of Aspergillus fumigatus and related species. Mycology 2005, 97, 1316-1329. [CrossRef]

52. Ruiz-Moyano, S.; Hernández, A.; Galvan, A.I.; Córdoba, M.G.; Casquete, R.; Serradilla, M.J.; Martín, A. Selection and application of antifungal VOCs-producing yeasts as biocontrol agents of grey mould in fruits. Food Microbiol. 2020, 92, 103556. [CrossRef] [PubMed]

53. Ruiz-Moyano, S.; Martín, A.; Villalobos, M.; Calle, A.; Serradilla, M.J.; Córdoba, J.J.; Hernández, A. Yeasts isolated from figs (Ficus carica L.) as biocontrol agents of postharvest fruit diseases. Food Microbiol. 2016, 57, 45-53. [CrossRef] [PubMed]

54. Cordero-Bueso, G.; Mangieri, N.; Maghradze, D.; Foschino, R.; Valdetara, F.; Cantoral, J.M.; Vigentini, I. Wild Grape-Associated Yeasts as Promising Biocontrol Agents against Vitis vinifera Fungal Pathogens. Front. Microbiol. 2017, 8, 2025. [CrossRef]

55. Parafati, L.; Vitale, A.; Restuccia, C.; Cirvilleri, G. Biocontrol ability and action mechanism of food-isolated yeast strains against Botrytis cinerea causing post-harvest bunch rot of table grape. Food Microbiol. 2015, 47, 85-92. [CrossRef] [PubMed]

56. Crous, P.; Wingfield, M.J.; Guarro, J.; Hernández-Restrepo, M.; Sutton, D.A.; Acharya, K.; Barber, P.A.; Boekhout, T.; Dimitrov, R.A.; Dueñas, M.; et al. Fungal Planet description sheets: 320-370. Persoonia-Mol. Phylogeny Evol. Fungi 2015, 34, 167-266. [CrossRef] [PubMed]

57. Settanni, L.; Sannino, C.; Francesca, N.; Guarcello, R.; Moschetti, G. Yeast ecology of vineyards within Marsala wine area (western Sicily) in two consecutive vintages and selection of autochthonous Saccharomyces cerevisiae strains. J. Biosci. Bioeng. 2012, 114, 606-614. [CrossRef]

58. Bougreau, M.; Ascencio, K.; Bugarel, M.; Nightingale, K.; Loneragan, G. Yeast species isolated from Texas High Plains vineyards and dynamics during spontaneous fermentations of Tempranillo grapes. PLoS ONE 2019, 14, e0216246. [CrossRef]

59. Nisiotou, A.A.; Lianou, A.; Nychas, G.J.E. Yeast Populations Residing on Healthy or Botrytis-Infected Grapes from a Vineyard in Attica, Greece. Appl. Environ. Microbiol. 2007, 73, 2765-2768. [CrossRef]

60. Guzzon, R.; Franciosi, E.; Larcher, R. A new resource from traditional wines: Characterisation of the microbiota of "Vino Santo" grapes as a biocontrol agent against Botrytis cinerea. Eur. Food Res. Technol. 2014, 239, 117-126. [CrossRef]

61. Drumonde-Neves, J.; Franco-Duarte, R.; Lima, T.; Schuller, D.; Pais, C. Yeast Biodiversity in Vineyard Environments Is Increased by Human Intervention. PLoS ONE 2016, 11, e0160579. [CrossRef]

62. Castrillo, D.; Crego, E.R.; González, N.N.; Blanco, P. Yeast diversity on grapes from Galicia, NW Spain: Biogeographical patterns and the influence of the farming system. OENO One 2019, 53. [CrossRef] 
63. Longo, E.; Cansado, J.; Agrelo, D.; Villa, T.G. Effect of climatic conditions on yeast diversity in grape musts from northwest Spain. Am. J. Enol. Vitic. 1991, 42, 141-144.

64. García-Cela, E.; Crespo-Sempere, A.; Gil-Serna, J.; Porqueres, A.; Marin, S. Fungal diversity, incidence and mycotoxin contamination in grapes from two agro-climatic Spanish regions with emphasis on Aspergillus species. J. Sci. Food Agric. 2015, 95, 1716-1729. [CrossRef] [PubMed]

65. Rotolo, C.; Angelini, R.M.D.M.; Dongiovanni, C.; Pollastro, S.; Fumarola, G.; Di Carolo, M.; Perrelli, D.; Natale, P.; Faretra, F. Use of biocontrol agents and botanicals in integrated management of Botrytis cinerea in table grape vineyards. Pest Manag. Sci. 2018, 74, 715-725. [CrossRef]

66. Prendes, L.P.; Merín, M.G.; Fontana, A.R.; Bottini, R.A.; Ramirez, M.L.; De Ambrosini, V.I.M. Isolation, identification and selection of antagonistic yeast against Alternaria alternata infection and tenuazonic acid production in wine grapes from Argentina. Int. J. Food Microbiol. 2018, 266, 14-20. [CrossRef]

67. Bleve, G.; Grieco, F.; Cozzi, G.; Logrieco, A.; Visconti, A. Isolation of epiphytic yeasts with potential for biocontrol of Aspergillus carbonarius and A. niger on grape. Int. J. Food Microbiol. 2006, 108, 204-209. [CrossRef] [PubMed]

68. Rathnayake, R.M.S.P.; Savocchia, S.; Schmidtke, L.M.; Steel, C.C. Characterisation of Aureobasidium pullulans isolates from Vitis vinifera and potential biocontrol activity for the management of bitter rot of grapes. Eur. J. Plant Pathol. 2018, 151, 593-611. [CrossRef]

69. Choińska, R.; Piasecka-Jóźwiak, K.; Chabłowska, B.; Dumka, J.; Łukaszewicz, A. Biocontrol ability and volatile organic compounds production as a putative mode of action of yeast strains isolated from organic grapes and rye grains. Antonie van Leeuwenhoek 2020, 113, 1135-1146. [CrossRef] [PubMed]

70. Arrebola, E.; Sivakumar, D.; Korsten, L. Effect of volatile compounds produced by Bacillus strains on postharvest decay in citrus. Biol. Control 2010, 53, 122-128. [CrossRef]

71. Spadaro, D.; Gullino, M.L. State of the art and future prospects of the biological control of postharvest fruit diseases. Int. J. Food Microbiol. 2004, 91, 185-194. [CrossRef]

72. Lutz, M.C.; Lopes, C.A.; Rodriguez, M.E.; Sosa, M.C.; Sangorrín, M. Efficacy and putative mode of action of native and commercial antagonistic yeasts against postharvest pathogens of pear. Int. J. Food Microbiol. 2013, 164, 166-172. [CrossRef] [PubMed]

73. Carmona-Hernández, S.; Reyes-Pérez, J.J.; Chiquito-Contreras, R.G.; Rincon-Enriquez, G.; Cerdan-Cabrera, C.R.; Hernandez-Montiel, L.G. Biocontrol of postharvest fruit fungal diseases by bacterial antagonists: A review. Agronomy 2019, 9, 121. [CrossRef]

74. Jamalizadeh, M.; Etebarian, H.R.; Aminian, H.; Alizadeh, A. A review of mechanisms of action of biological control organisms against post-harvest fruit spoilage. EPPO Bull. 2011, 41, 65-71. [CrossRef]

Publisher's Note: MDPI stays neutral with regard to jurisdictional claims in published maps and institutional affiliations.

(C) 2020 by the authors. Licensee MDPI, Basel, Switzerland. This article is an open access article distributed under the terms and conditions of the Creative Commons Attribution (CC BY) license (http://creativecommons.org/licenses/by/4.0/). 